\title{
Investigating the Agriculture-Animal Husbandry Potentials of Trainees Who Receive Training at DAP Farmer Training Center at Van Yuzuncu Yil University
}

\author{
Serhat YILDIZ1 $\quad$ Suna AKKOL ${ }^{2}$ Suphi DENIZ ${ }^{3}$ \\ ${ }^{1}$ Van Yuzuncu Yil University, Vocational School of Gevas, Department of Veterinary, Van, Turkey \\ 2 Van Yuzuncu Yil University, Faculty of Agriculture, Department of Biometry and Genetics, Van, Turkey \\ ${ }^{3}$ Van Yuzuncu Yil University, Faculty of Veterinary Medicine, Department of Animal Nutrition and Nutritional Diseases, Van, Turkey
}

Received: 11.02 .2019

Accepted: 01.10.2019

ABSTRACT This study was carried out with the purpose of determining the general statuses and current production infrastructures of farmers in the province of Van in Turkey who deal with agriculture and animal husbandry and providing recommendations by finding out about the problems that lead to reduction in production. For this purpose, survey forms that were held with trainees who attended training programs at DAP (Eastern Anatolian Project) Farmer Training Center at Van Yuzuncu Yil University were utilized. The vast majority $(89.51 \%)$ of the participants of these training programs consisted of low-income individuals, and a significant part among these individuals (37.90\%) owned agricultural land with areas in the range of 5-20 da. The ratios of those who acquired the coarse feeds and concentrate feeds that were used at their establishment from outside were found respectively as $21.55 \%$ and $43.56 \%$. Most participants stated that they grazed their animals in forage land (90.87\%) and did not use silage (81.60\%). $60.37 \%$ of the participants took part in cattle breeding, $28.11 \%$ took part in sheep breeding, $53.54 \%$ were not involved in any agricultural association, and $58.18 \%$ did not receive agriculture-related assistance. The main problem in the establishments was determined as feeds and feeding the animals $(25.75 \%)$, which were followed by health problems (21.89\%).

Keywords: Enterprise Structure, Feed and Nutrition Problems, Mechanization, Health

ÖZ

\section{Van Yüzüncü Yıl Üniversitesi DAP Çiftçi Eğitim Merkezi'nde Eğitim Alan Kursiyerlerin Tarım-Hayvancılık Potansiyellerinin Değerlendirilmesi}

$\mathrm{Bu}$ çalışma, Van ilinde tarım ve hayvancılıkla uğraşan çiftçilerin genel durumlarını ve mevcut üretim altyapılarını belirlemek, üretimin azalmasına neden olan sorunların saptanarak çözüm önerilerinde bulunmak amacıyla yapılmıștır. Bu amaçla, Van Yüzüncü Yıl Üniversitesi DAP (Doğu Anadolu Projesi) Çiftçi Eğitim Merkezi'nde eğitimlere katılan kursiyerlerle yapılan anketler kullanılmıştır. Eğitimlere katılanların büyük çoğunluğu düşük gelirli (\%89.51) bireylerden oluşmakta ve önemli bir bölümünün 5-20 da (\%37.90) tarım arazisine sahip oldukları belirlenmiştir. İşletmede kullanılan kaba ve kesif yemleri, dışarıdan temin edenlerin oranı sırasıyla \%21.55 ve \%43.56 olarak bulunmuştur. Ankete katılanların çoğunluğunun hayvanlarını merada (\%90.87) otlattıkları ve silaj kullanmadıkları (\%81.60) belirlenmiștir. Ankete katılanların \%60.37'sinin sığırcılıkla, \%28.11'inin koyunculukla uğraştıkları, herhangi bir tarımsal örgütlenmede yer almayanların oranı \%53.54 ve tarımsal desteklerden faydalanmayanların oranı ise \%58.18 olarak tespit edilmiștir. İşletmelerde yem ve hayvan besleme sorunu (\%25.75) temel sorun olarak belirlenmiş, bunu sağlık sorunları (\%21.89) izlemiştir.

Anahtar Kelimeler: İşletme Yapısı, Yem ve Beslenme Sorunları, Mekanizasyon, Sağlık

\begin{abstract}
GíRiş
Ülkemizin Doğu Anadolu Bölgesi'nde bulunan Van ili, şiddetli karasal bir iklime sahip olmakta birlikte, ülkenin en fazla güneş alan illerinden biridir. Van İli 2.100.300 ha alana sahip olup, arazilerinin \%17.72'sini tarım, \%64.71'ini çayır-mera, \%1.25'ini orman fundalık ve \%16.32'sini de tarım dıșı arazi oluşturmaktadır. Toplam
\end{abstract}

tarım arazisinin \%27.2'si hububat ekim alanı, \%28.1'i yem bitkileri ekim alanı, \%0.5'i diğer tarla ürünleri ekimi, $\% 1.2$ 'si bağ-meyve tarımı, \%0.4'ü açıkta sebze üretim alanı, \%30.8'i nadas alanı ve \%1.8'ini kullanılmayan tarım arazileri olușturmaktadır. Van İli'nde 372.196 hektar tarım arazisinin 123.173 hektarı (\%33.1) sulanmaktadır. Kaba yemler içerisinde çayır-meralar toplam üretimin 
\%43.4'ünü olușturmakta, yem bitkilerinin payı ise \%44.4'tür. Toplamda 119.733 ha çayır alanları, 1.239.289 ha mera alalarına sahiptir (Anonim 2013; TÜIK 2018a). Van ili, Türkiye'de hayvancılık faaliyetlerinin en yoğun olarak yapıldığı iller arasında yer almaktadır. 2017 verilerine göre Van ilinde her yaşta toplam 186.099 büyük baș ve 2.738.054 küçükbaş hayvan bulunurken Ülke genelinde ise toplam 16.103 .025 büyük baş ve 44.312 .308 küçükbaş hayvan bulunmaktadır (TÜİK 2018b).

Hayvancılık faaliyetlerinden elde edilen ürünlerin başında süt ve süt ürünleri ile et ve et ürünleri gelmektedir. Küçükbaş hayvancılık kapsamında koyun sütü üretiminde 119.209 ton ile lider kent konumundadır. Bunun yanında Van ili keçi sütü üretiminde de 9.843 ton ile 8. sıra ile ülkenin önemli kentleri arasındadır. Kırmızı et üretiminde ise Van ili büyükbaş hayvancılıkta orta sıralarda, küçükbaş hayvancılıkta ise üst sıralardadır. Büyükbaş ve küçükbaş hayvancılık faaliyetlerinin en temel girdisi yemdir. Ayrıca yem, büyükbaş ve küçükbaş hayvancılık faaliyetlerindeki maliyetlerin büyük bir kısmını olușturmaktadır. Mevcut durumda yem bitkileri, Van ilinde en fazla alanda yetiştiriciliği yapılan tarımsal üründür. Ayrıca, yem bitkileri tarımının yüksek olması, tarıma dayalı sanayiinin gelişmesine de yardımcı olmaktadır (TÜİK 2018a).

Ülkelerin kalkınması için lokomotif güce sahip sektörlerin bașında eğitim faaliyetleri gelmektedir. Tarımsal faaliyetleri gelişmiş ülkelere bakıldığında, bunların tarımsal eğitime de önem verdikleri görülmektedir. Ülkemizde ve özellikle Doğu Anadolu Bölgesi'nde, tarım sektöründe çalışanların büyük çoğunluğu eğitim seviyesi düşük bireylerden oluşmaktadır. Van Yüzüncü Yıl Üniversitesi, DAP Çiftçi Eğitim Merkezi'nde tarımsal faaliyetler kapsamında verilen eğitimlere katılan kursiyerlerle yapılan bir çalışmada, kursiyerlerin eğitim düzeylerinin çok düşük olduğu (ilköğretim ve altı \%78.91), bu kursiyerlerin sadece \%21.72'sinin daha önce herhangi bir tarımsal eğitim aldığı tespit edilmiştir (Yıldız ve ark. 2019).

Ülkemizde kırsal alanda yaşayan insanların birçoğu geçimini tarımsal faaliyetlerden sağlamaktadır. Kullanılabilir arazi kaynakları sınırlı olduğundan, kırsal kesimin hayat standardını yükseltmek ve daha iyi bir yașam düzeyini sağlamak, tarımda sınırlı üretim kaynaklarından en iyi şekilde yararlanmakla mümkün olacaktır. $\mathrm{Bu}$ nedenle, Van ilinde mevcut tarımsal faaliyetlerle uğraşan çiftçilerin genel durumlarını ve mevcut üretim altyapılarını belirlemek, üretimin azalmasına yol açan sorunların saptanarak çözüm önerilerinde bulunmak amacıyla, Van Yüzüncü Yıl Üniversitesi DAP Çiftçi Eğitim Merkezi'nde eğitimlere katılan kursiyerlerle bu çalıșma yapılmıștır.

\section{MATERYAL ve METOT}

Van Yüzüncü Yıl Üniversitesi DAP Çiftçi Eğitim Merkezi'nde eğitimlere katılan 250 kursiyer ile yüz yüze gerçekleştirilen görüşmelerle yapılan anketlerden elde edilen veriler, çalışmanın materyalini oluşturmuştur. Eğitimlere Van ilinin Bahçesaray, Çatak, Edremit, İpekyolu, Muradiye, Tuşba ve Özalp ilçelerinden katılımlar gerçekleşmiştir. Anket çalışması Mayıs 2017-Mayıs 2018 tarihleri arasında yapılmıștır. Anket sorularının değerlendirilmesinde SAS (2014) paket programı kullanılmış ve verilere ki-kare $\left(\chi^{2}\right)$ test istatistiği uygulanmıştır.

\section{BULGULAR}

\section{Eğitimlere katılan kursiyerlerin bazı özellikleri}

Eğitimlere katılan çiftçilerin (kursiyer) büyük çoğunluğunun 31-40 yaşları arasında (\%30.00) olduğu; kadın kursiyerlerin oranı \%5.65, erkek kursiyerlerin oranı \%94.35; evli olanların oranı \%80.17, bekâr olanların oranı ise \%19.92 olarak belirlenmiștir. Ankete katılanların \%56.68'inin 5-6 ve daha fazla sayıda çocuğa sahip olduğu ve hane halkı sayısına göre çoğunlukla 6-7 kişi ve daha kalabalık ailelerden (\%74.50) meydana geldiği tespit edilmiştir. Eğitim düzeyleri incelendiğinde, okula gitmeyenlerin oranı \%13.36, okur-yazar olanların oranı $\% 19.43$, ilkokul mezunu olanların oranı $\% 22.27$, ortaokul mezunu olanların oranı $\% 19.03$, lise ve dengi okul mezunu olanların oranı \%10.93, üniversite mezunu olanların oranı ise \%4.45 olduğu belirlenmiştir (Tablo 1).

\section{Gelir-gider durumu}

Eğitimlere katılan kursiyerlerin büyük çoğunluğu, kendi evlerinde (\%80.42) ikamet ettiklerini ve 2000 TL'nin altında aylık gelire (\%89.51) sahip olduklarını ifade etmişlerdir. Kursiyerlerin \%70.89'unun tarım dışı gelirlerinin olmadığı, hayvancllık ile birlikte yapılan diğer tarımsal faaliyetlerin ise \%11.86' 1 meyvecilik, \%11.86' 1 sebzecilik, \%60.45'i tarla tarımı, \%11.30'u ticaret ve \%4.52'si diğer faaliyetler olduğu belirlenmiștir. Gider kalemlerinden olan veteriner hekim hizmeti alanların oranı \%48.84 ve almayanların oranı ise \%51.16 olarak belirlenmiştir (Tablo 2).

\section{Hayvanların besleme durumu}

Eğitimlere katılan kursiyerlerin, hayvanları beslemek için kaba ve kesif yemleri, dışarıdan temin edenlerin oranı sırasıyla \%21.55 ve \%43.56 olmuștur. Kursiyerlerin çoğunluğunun hayvanlarını merada otlattıkları (\%90.87) ve silaj kullanmayanların çoğunlukta (\%81.60) olduğu belirlenmiștir. Yetiștiricilerin, hayvanların ihtiyaç duydukları tuz ve vitamin-mineral takviyelerini her gün (\%17.12), haftada bir kez (\%30.63), ayda bir kez (\%22.97), yılda $1-2 \mathrm{kez}(\% 16.22)$ ya da hiç vermedikleri (\%13.06) belirlenmiştir (Tablo 3).

\section{İşletme büyüklüğü ve hayvancılıkta makine kullanımı}

Kursiyerlerin \%37.90'ının 5-20 da, \%25.57'sinin 20-50 da, \%19.63'nün 50-100 da tarım arazisini işledikleri tespit edilmiştir. Hayvancılık faaliyetlerini kolaylaştıran tarımsal alet ve makine kullanımında ilk sırayı traktör kullanımı (\%68.15) ve daha sonra ise sırasıyla; süt sağım makinası (\%14.07), yem karıștırma makinası (\%8.89), yem kırma makinası (\%4.44), diğer makinalar (\%2.96) ve elektrikli kırkım makinasının (\%1.48) oluşturduğu belirlenmiștir (Tablo 4).

\section{Hayvansal ürün elde edilmesi ve pazarlama}

Kursiyerlerin uğraştıkları hayvancılık faaliyetlerine bakıldığında, \%60.37'sinin sığırcılıkla, \%28.11'inin koyunculukla uğraștıkları; ortalama hayvan sayısının sığırlarda 9.25, koyunlarda 71.12, olduğu belirlenmiștir (Tablo 5).

\section{Tarımsal örgütlenme ve destekler}

Kursiyerlerin büyük çoğunluğunun herhangi bir tarımsal örgütlenmede yer almadıkları (\%53.54), ancak bir bölümünün (\%18.58) tarımsal örgütlere üye olmaya istekli oldukları gözlenmiştir. Kursiyerlerin \%41.82'sinin tarımsal desteklerden faydalandığı, \%58.18'inin faydalanmadığı belirlenmiştir. 


\section{Hayvancılık faaliyetlerindeki sorunlar}

Kursiyerlerin hayvancılık faaliyetlerinde karşılaştıkları sorunların başında yem ve hayvan besleme sorunu (\%25.75) yer alırken, bunu sırasıyla, sağlık (\%21.89), kredi ve destekleme (\%8.15), damılık (\%6.01), bilgi ve eğitim (\%3.86), altyapı (\%3.43), pazarlama-satış (\%3.00) sorunu izlemektedir. Kursiyerlerin çoğunun (\%72.37) bırakmayı düșünmediği tespit edilmiștir (Tablo 7). Çalışmada öğrenim durumu ve koyun-keçi varlığı ile diğer değişkenler arasında Ki-kare testi kullanılarak bağımsızlık testi yapılmış ve sonuçlar Tablo 8'de verilmiștir. Tablo 8 incelendiğinde değişkenler arasında herhangi anlamlı bir ilişki olmadığı görülmektedir.

Tablo 1. Eğitimlere katılan çiftçilerin bazı özellikleri

Table 1. Some characteristics of farmers participating in trainings

\begin{tabular}{llll}
\hline Çocuk Sayısı & $\mathbf{\%}$ & Yaş & $\mathbf{\%}$ \\
$1-2$ çocuk & 13.36 & 20 ve altı & 5.60 \\
$3-4$ çocuk & 19.43 & $21-30$ & 22.00 \\
$5-6$ çocuk & 22.27 & $31-40$ & 30.00 \\
7-8 çocuk & 19.03 & $41-50$ & 22.00 \\
$9-10$ çocuk & 10.93 & $51-60$ & 15.20 \\
11 ve üzeri çocuk & 4.45 & 61 ve üzeri & 5.20 \\
Çocuk yok & 10.53 & & \\
Öğrenim Durumu & & Hane halkı Sayısı & 0.40 \\
Okula gitmemiş & 13.36 & Tek & 8.50 \\
Okur-yazar & 19.43 & $2-3$ kiși & 16.60 \\
İlkokul mezunu & 22.27 & $4-5$ kiși & 25.10 \\
Ortaokul mezunu & 19.03 & $6-7$ kși & 23.89 \\
Lise mezunu & 10.93 & $8-9$ kiși & 16.60 \\
Üniversite & 4.45 & $10-11$ kişi & 8.91 \\
Diğer & 10.53 & 12 ve üzeri & \\
Medeni Durum & & Cinsiyet & 5.65 \\
Evli & 80.17 & Kadın & 94.35 \\
Bekâr & 19.92 & Erkek & \\
\hline
\end{tabular}

Tablo 2. Gelir-gider durumu

Table 2. Income-expenditure situation

\begin{tabular}{llll}
\hline Evin Mülkiyeti & $\mathbf{\%}$ & Aylık Gelir (TL) & $\mathbf{\%}$ \\
Kendi evi & 80.42 & Asgari ücretten az & 44.10 \\
Kira & 13.75 & Asgari ücret & 23.58 \\
Lojman & 5.00 & $1.501-2.000$ arası & 21.83 \\
Başka & 0.83 & $2.001-2.500$ arası & 3.93 \\
Diğer Faaliyetler & & $2.501-3.000$ arası & 2.62 \\
Meyvecilik & 11.86 & $3.001-3.500$ arası & 2.18 \\
Sebzecilik & 11.86 & $3.501-4.000$ arası & 1.31 \\
Tarla tarımı & 60.45 & $4.001-4500$ arası & 0.44 \\
Ticaret & 11.30 & $4.501-5.000$ arası & 0.00 \\
Diğer & 4.52 & 5.001 ve üzeri & 0.00 \\
Veteriner Hekim Hizmeti & & Ek Gelir & 70.89 \\
Evet & 48.84 & Yok & 7.98 \\
Hayır & 51.16 & Kira & 19.72 \\
& & Ek iş & 1.41 \\
\hline
\end{tabular}

Tablo 3. Hayvanların besleme durumu

Table 3. Feeding status of animals

\begin{tabular}{|c|c|c|c|}
\hline Kaba Yemlerin Temini & $\%$ & Kesif Yemlerin Temini & $\%$ \\
\hline Mera- biçenekleri & 24.14 & Kendi üretimi & 23.11 \\
\hline Kendim üretimi & 22.41 & Dişarıdan temin & 43.56 \\
\hline Dișarıdan temin & 21.55 & Kendi üretimi ve dıșarıdan temin & 25.33 \\
\hline Kendi üretimi ve dișarıdan temin & 18.97 & Diğer & 1.78 \\
\hline Diğer & 0.43 & $\begin{array}{l}\text { İki veya daha fazla parametre } \\
\text { seçenler* }\end{array}$ & 6.22 \\
\hline İki veya daha fazla parametre seçenler* & 12.50 & & \\
\hline Tuz ve Vitamin-Mineral Takviyesi & & $\begin{array}{l}\text { Silaj Bitkilerinin Üretim ve } \\
\text { Kullanım Durumu }\end{array}$ & \\
\hline Yok & 13.06 & Evet & 18.40 \\
\hline Yılda 1-2 kere & 16.22 & Hayır & 81.60 \\
\hline Ayda bir kere & 22.97 & Hayvanlar Meraya Çıkıyor Mu? & \\
\hline Haftada bir kere & 30.63 & Evet & 90.87 \\
\hline Her gün düzenli & 17.12 & Hayır & 9.13 \\
\hline
\end{tabular}


Tablo 4. İşletmelerin büyüklüğ̈ ve hayvancılıkta makine kullanımı

Table 4. Businesses size and use of machinery in livestock

\begin{tabular}{|c|c|c|c|c|}
\hline $\begin{array}{l}\text { Kullanılan Tarım Arazisi Miktarı } \\
\text { (Da) }\end{array}$ & $\%$ & \multicolumn{2}{|c|}{$\begin{array}{l}\text { Hayvancılıkta Kullanılan Zirai Alet ve } \\
\text { Makinalar }\end{array}$} & $\%$ \\
\hline $5-20$ & 37.90 & \multicolumn{2}{|c|}{ Traktör } & 68.15 \\
\hline $20-50$ & 25.57 & \multicolumn{2}{|c|}{ Yem karıștırma makinası } & 8.89 \\
\hline $50-100$ & 19.63 & \multicolumn{2}{|c|}{ Yem kırma makinası } & 4.44 \\
\hline $100-250$ & 5.94 & \multicolumn{2}{|c|}{ Süt sağım makinası } & 14.07 \\
\hline $250-500$ & 4.57 & \multicolumn{2}{|c|}{ Elektrikli kırkım makinası } & 1.48 \\
\hline $500-1000$ & 3.20 & \multicolumn{2}{|c|}{ Diğer } & 2.96 \\
\hline 1000 ve üzeri & 3.20 & & & \\
\hline Tarım Arazilerinin Sulama Durumu & & En Az & En Çok & Ortalama \\
\hline Sulu & & 2 & 3500 & 73.02 \\
\hline Kıraç & & 1 & 900 & 66.62 \\
\hline
\end{tabular}

Tablo 5. Hayvansal ürün elde edilmesi ve pazarlama

Table 5. Animal product acquisition and marketing

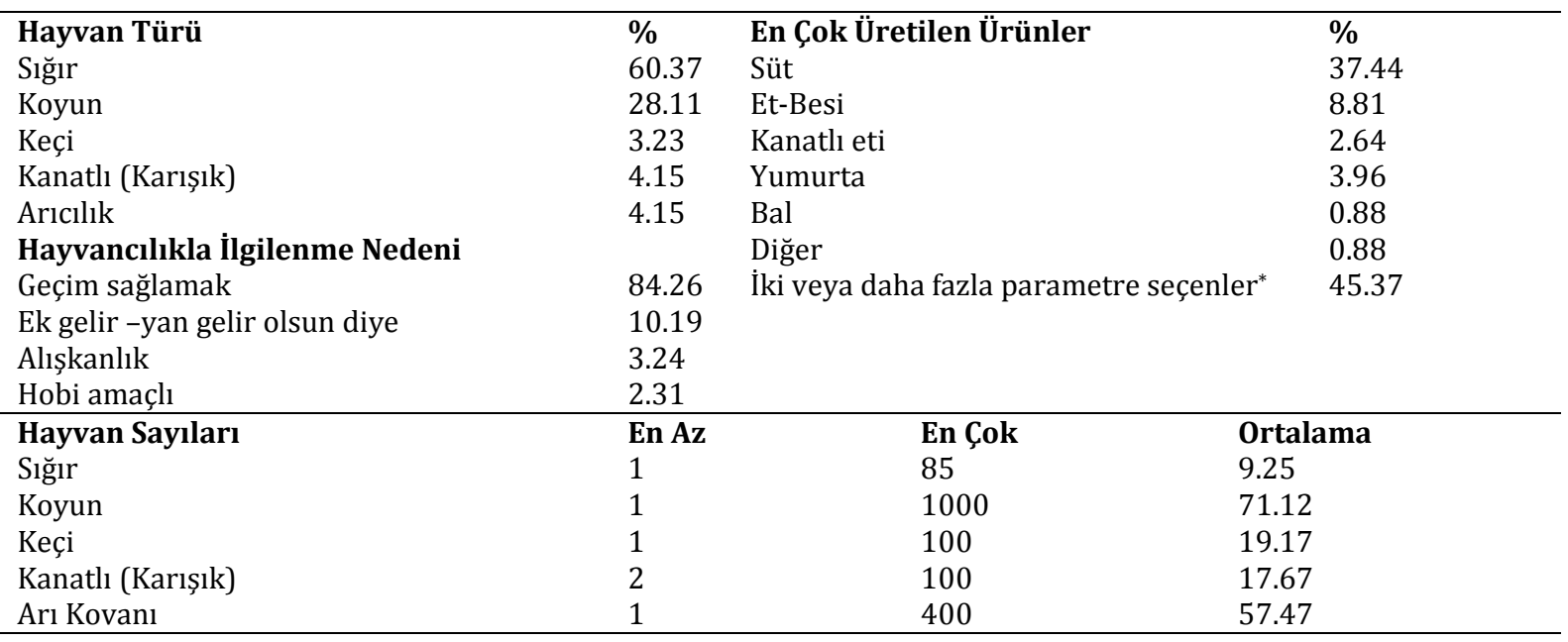

*Bu sorularda iki veya daha fazla seçeneği seçenler bulunmaktadır.

Tablo 6. Tarımsal örgütlenme ve desteklerden faydalanma durumu

Table 6. Agricultural organization and benefiting from support

\begin{tabular}{llll}
\hline Tarımsal Örgütlere Üyelik & $\mathbf{\%}$ & Tarımsal Destek Durumu & $\mathbf{\%}$ \\
Yok & 53.54 & Evet & 41.82 \\
Tarımsal kalkınma kooperatifi & 7.52 & Hayır & 58.18 \\
Sulama kooperatifi & 1.77 & & \\
Tarım kredi kooperatifi & 8.85 & & \\
Damızlık birliği & 9.73 & & \\
Üye değil fakat istekli & 18.58 & & \\
\hline
\end{tabular}

Tablo 7. Hayvancılık faaliyetlerindeki sorunlar

Table 7. Problems in livestock activities

\begin{tabular}{lllc}
\hline EN BÜYÜK SORUNLAR & $\mathbf{\%}$ & FAALIYYTLERİN BIRAKMA DURUMU & $\%$ \\
Sağlık & 21.89 & Hiç Düşünmüyor & 49.56 \\
Damızlık & 6.01 & Düşünmüyor & 22.81 \\
Alt yapı & 3.43 & Kararsız & 16.67 \\
Yem ve besleme & 25.75 & Düşünüyor & 9.65 \\
Pazarlama satış & 3.00 & Illk firsatta hayvancıllk faaliyetini bitirecek & 1.32 \\
Kredi ve destekleme & 8.15 & & \\
Bilgi ve eğitim & 3.86 & & \\
İki veya daha fazla parametre seçenler* & 27.90 & & \\
\hline
\end{tabular}

*Bu soruda iki veya daha fazla seçeneği seçenler bulunmaktadır. 
Tablo 8. Öğrenim durumu ve koyun keçi varlığı ile diğer bazı değişkenler arasındaki ilişki

Table 8. Relationship between educational status and presence of sheep goat and some other variables

\begin{tabular}{llllc}
\hline & \multicolumn{2}{c}{ Öğrenim Durumu } & \multicolumn{2}{c}{ Sı̆̆ır-koyun varlı̆̆ } \\
\cline { 2 - 5 } & \multicolumn{1}{c}{$\mathbf{X}^{\mathbf{2}}$} & \multicolumn{1}{c}{$\mathbf{P}$} & \multicolumn{1}{c}{$\mathbf{X}^{\mathbf{2}}$} & $\mathbf{P}$ \\
\hline Veterinerlik hizmeti alıp almadığı & 7.0551 & 0.2166 & 1.2008 & 0.2732 \\
Tuz ve vitamin-mineral takviyesi yapıp yapmadığı & 7.1761 & 0.2079 & 0.8012 & 0.3707 \\
Tuz ve vitamin-mineral takviyesi sıklığı & 16.6897 & 0.6730 & 3.0897 & 0.5429 \\
Tarımsal örgütlere üye olup olmadığı & 5.7744 & 0.3288 & 0.5808 & 0.4460 \\
Hayvan varlığı & 16.8200 & 0.6646 & - & - \\
Sığır-koyun varlığı & 4.1239 & 0.5317 & - & - \\
\hline
\end{tabular}

\section{TARTIŞMA ve SONUÇ}

Araștırmaya konu olan ve DAP Çiftçi Eğitim Merkezi'nde verilen eğitimlere katılan kursiyerlerin \%57.60'ının 40 yaş ve altında olduğu ve genç bir kitlenin eğitim almak istemesinin tarımsal faaliyetlerin geleceği açısından umut verici olduğu görülmektedir. Van ili Gevaş ilçesinde süt sığırcılı̆̆ üretim faaliyetinde bulunan 44 işletmenin sosyodemografik ve işletmecilik özellikleri bakımından karşılaştırıldığı bir çalışmada, işletme sahiplerinin yaş ortalamasının 44.6 olduğu bildirmiştir (Gençdal ve ark. 2016). Bu değer, yapılan bu çalışmada tespit edilen değerden düşüktür. Kadın kursiyerlerin oranının (\%5.65) erkek kursiyerlerden (\%94.35) çok daha az olduğu, eğitimlere katılanların büyük çoğunluğunun evli bireyler (\%80.17) olduğu, yine hane halkı sayısına göre büyük çoğunluğunun 6-7 ve daha kalabalık ailelerden (\%74.50) oluştuğu tespit edilmiştir. Van ilinde 2017 yılı ortalama hane halkı büyüklügünün 5.2 kişi olduğu (TÜíK 2017a) dikkate alındığında, ankete katılan kursiyerlerin hane halkı büyüklüğünün Van ili ortalamasının üzerinde olduğu belirlenmiştir. Dedeoğlu ve Yıldırım (2006)'ın Emek Tarımsal Kalkınma Kooperatifi'ne ortak ișletmelerin ekonomik analizini yaptıkları bir çalıșmada, incelenen işletmelerde ortalama hane halkı büyüklüğü 6 kişi olduğunu ortaya koymuştur. Bu sonuç, çalışmadan elde edilen bulgu ile uyumlu bulunmuștur. Karaturhan ve ark. (2014) tarafından yapılan bir çalıșmada, ankete katılan kursiyerlerin \%99'unun erkeklerden, \%1'inin kadınlardan oluştuğu bildirilmiştir. Bu çalışmada, eğitimlere katılan kadınların bu oranın üstünde olması, olumlu bir gelişme olarak görülmektedir.

Yaşam kalitesini belirleyen kriterler arasında ikamet edilen ev ve evin mülkiyeti önemlidir (Yavuz ve ark 2014). Yapılan bu çalışmada, elde edilen verilere göre ankete katılanların büyük çoğunluğunun ikamet ettiği evin mülkiyetinin (\%80.42) kendilerine ait olduğu belirlenmiştir. 2016 yılı gelir ve yaşam istatistiklerine göre Türkiye'de yaşayan fertlerin konut mülkiyetleri kendilerine ait olanların oranının $\% 59.70$ olduğu bildirilmektedir (TÜİK 2017b). Bu çalışmada elde edilen oranın 2016 yılı istatistik verilerinden daha yüksek olduğu tespit edilmiştir. Bu sonuç, ankete katılan kursiyerlerin büyük bölümünün kırsal alanda ikamet etmesinden kaynaklanmaktadır. Yaşam kalitesini arttıran faktörlerden bir diğeri de gelir düzeyidir. Çiftçi eğitimlerine katılan kursiyerlerin aylık gelirleri incelendiğinde, çoğunluğun gelirinin asgari ücret ve altı (\%67.68) olduğu görülmektedir (Tablo 2). 2016 yılı tarımsal işletme işgücü ücret yapısı istatistiklerine göre, Türkiye'deki sürekli tarım işçilerinin ortalama aylık ücretlerinin $1677 \mathrm{TL}$ olduğu (TÜIK 2017c) ve bu değerin, bu çalışmada elde edilen değerden daha yüksek olduğu belirlenmiştir. Ankete katılanların çoğunluğu gelirlerini arttırmak için çiftçilik dışında ek geliri olmadığını (\%70.89) ifade etmişlerdir. Bu durum, geçimlerini sağlamak için çiftçilikten başka alternatiflerinin olmadığını, bu sektöre bağımlı olduklarını göstermektedir. Hozman ve Akçay (2016) yaptıkları bir çalıșmada, ankete katılanların \%63'ünün tarım dıșı geliri olmayan bireylerden oluştuğunu, \%37'sinin ise tarım dışı gelire sahip olduklarını bildirmişlerdir.

Hayvancılıkla birlikte yapılan diğer faaliyetlerde tarla tarımı (\%60.45) ilk sırada yer almakta, bunu meyvecilik (\%11.86), sebzecilik (\%11.86), ticaret (\%11.30) ve diğer işler (\%4.52) izlemektedir. Hozman ve Akçay (2016)'ın yaptıkları çalışmada, ankete katılan üreticilerin \%17.2'si sadece bitkisel üretim, \%32.3'ü hayvansal üretim ve \%50.3'ünün ise, karma üretim yaptı̆̆ı ortaya konmuştur. Yapılan bu çalışmada, ankete katılan ve hayvancılık faaliyeti yapan kursiyerlerin \%48.84'ünün veterinerlik hizmeti aldıkları belirlenirken, Karakuş ve Akkol (2013) ise, hedef kitle çiftçilerin \%52.64'ünün veteriner hekim hizmeti aldığını bildirmişlerdir.

DAP Çiftçi Eğitim Merkezi'nde verilen eğitimlere katılan kursiyerlerin kullandıkları kaba ve kesif yemleri sırasıyla, $\% 46.55$ ve $\% 23.11$ 'inin kendisinin ürettiği, $\% 21.55$ ve \%43.56'inin dışarıdan satın aldığı, \%18.97 ve \%25.33'nün ise, hem kendisinin ürettiği, hem de dişarıdan satın aldığı belirlenmiștir. Karakuş ve Akkol (2013)'un yaptıkları çalışmada ise, kaba ve kesif yemleri sırasıyla \%12.26 ve $\% 5.65$ 'inin işletmenin kendisinden, \%17.22 ve \%15.86'sının dişarıdan satın aldığı, \%70.52 ve \%78.49'unun ise, hem kendisinin ürettiği, hem de dışarıdan satın aldığı bildirilmiştir.

İşletme giderlerinin azaltması ve sağlıklı bir hayvancılık için hayvanların meraya çıkarılması hayati öneme sahiptir. İncelenen hedef kitledeki yetiştiricilerin \%90.87'sinin hayvanlarını meraya çıkarttıkları belirlenmiștir. Bu oran, Şahin ve Yılmaz (2008)'ın yaptıkları çalışmada elde edilen değerden (\%76.22) daha yüksektir. Kârlı bir hayvancıllğın önemli bir faktörü olan silajın, ancak yetiştiricilerin \%18.40'ı tarafından kullanıldığı belirlenirken, bu oran Şahin ve Keskin (2010)'in yaptığı çalışmada \%25.20 olarak bildirilmiştir. Kursiyerlerin yetiştirdikleri hayvanların beslenmesinde tuz ve vitamin-mineral takviyesini yllda bir, ayda bir, haftada bir ve hiç kullanmayanların oranı sirasiyla $\% 16.22, \% 22.97, \% 30.63$ ve $\% 13.06$ olarak belirlenirken, tuz ve vitamin-mineral katkısını her gün düzenli olarak yapan yetiștiricilerin oranı \%17.12'de kalmıştır. Karakuş ve Akkol (2013)'un çalışmalarında ise, tuz ve vitamin-mineral takviyesini yapanların oranı $\% 57.95$, yapmayanların oranı ise $\% 42.05$ olarak bildirilmiştir. Modern hayvancılıkta kullanılan, bitkisel üretim ve hayvancılık yapmayı kolaylaştıran, çiftçiler tarafından en çok tercih edilen zirai alet ve makinaların, işletme başına 0.68 adet traktör (\%68.15) ve 0.14 adet süt sağım makinası (\%14.07) olduğu belirlenmiștir. Güzel ve Aybek (2017) yaptığı çalışmada ele aldıkları 
işletmelerdeki alet ve makinaların sayısının işletme ölçeği büyüdükçe sayının arttığı, ișletme bașına ortalama traktör sayısının 0.76 ve tüm makine sayısının ise 8.59 adet, bunun 1.05'inin ise süt sağım makinesi olduğu bildirilmiştir. Eğitimlere katılan kursiyerlere yapılan ankette \%60.37'sinin sığırcllıkla, \%28.11'inin koyunculukla uğraștığı ve kişi başına ortalama 9.25 baş sığır ve 71.12 baş koyuna sahip oldukları tespit edilmiştir. Şahin ve Yılmaz (2008) çalışmalarında, işletmelerin \%77.0'sinin büyükbaş hayvanlara, \%69.7'sinin küçükbaş hayvanlara sahip olduklarını, bunun da işletme başına 4.61 BBHB (Büyükbaș Hayvan Birimi) büyükbaș, 36.08 baș küçükbaş hayvana karşılık geldiğini bildirilmektedirler. Bu değerlerin yapılan bu çalışmadan elde edilen değerlerden düşük olduğu görülmektedir. Tarımsal faaliyetlerle uğraşanlar için örgütlenme; mevcut sosyal yapı içinde birlikte karar alma ve sorumluluk bilincine sahip olarak insan kaynakları ve fiziki imkanları birleştirerek ortak tutum, davranış ve alışkanlıkların geliştirilmesine olanak sağlayan bir yapılanma olarak tanımlanmaktadır (Karaturhan ve ark 2014). Buna göre, yapılan bu çalışmada ankete katılan kursiyerlerin büyük çoğunluğunun herhangi bir tarımsal örgüte üye olmadıkları (\%53.54), üye olmak isteyenlerin oranının ise, \%18.58 olduğu belirlenmiștir. Karakaya ve Kızıloğlu (2014)'nun çalışmasında ankete katılan yetiştiricilerden herhangi bir tarımsal örgüte üye olmayanların oranı \%42 olarak belirlenmiș ve bu değer, bu çalışmada elde edilen değerden daha düşük bulunmuştur. Ayrıca herhangi bir tarımsal destekten faydalanma durumu incelendiğinde, kursiyerlerin \%41.82'sinin faydalandığı, \%58.18'inin faydalanmadığı ifade edilmiștir. Demir ve ark (2015)'nın yaptığı çalıșmada ise, ankete katılan üreticilerin \%87.9'unun devlet teşviği ya da desteği aldığı, \% 12.1'inin almadığı bildirilmiștir. Bu değerlerin bu çalışmadan elde edilen değerlerden yüksek olduğu görülmektedir.

Yapılan bu çalışmada elde edilen bulgulara göre, ankete katılanların hayvancılık faaliyetlerinde yaşadıkları sorunlarının sirasiyla; yem ve besleme (\%25.75), hayvan sağlı̆̆ı (\%21.89), kredi ve destekleme (\%8.15), damızlık (\%6.01), bilgi ve eğitim (\%3.86), altyapı (\%3.43), pazarlama sorunları (\%3.00) olduğu tespit edilmiştir. Karakaya ve Kızıloğlu (2014)'nun yapmış olduğu anket çalışması sonuçlarına göre ise, yetiştirici sorunlarının \%36'sı ürünlerinin pazar imkanlarının arttırılması, yine \%36'sı veteriner hekim hizmeti konularında yetkililerden beklentilerinin olduğu, hayvancılık eğitimi konusunda beklentisi olan yetiştiricilerin oranının ise, \%3 olduğu bildirilmiştir. Bu değerler, yapılan bu çalışma ile ortak parametrelerden elde edilen değerlerden (eğitim sorunu hariç) daha yüksek olduğu görülmektedir.

Sonuç olarak; kırsal kesimde yașayan insanlar ve çiftçiler, ülke kalkınmasını etkileyen önemli aktörlerdir. Kırsal kesimde yaşayan insanların çoğunluğu geçimini bitkisel üretim ve hayvancılıktan sağlamaktadır. Tarımsal faaliyetlerde üretim, gelir ve refah artışının sağlanabilmesi için üreticilerin etkin bir șekilde bilinçlendirilmiș olması oldukça önemlidir. Van'da tarımsal faaliyetlerle uğraşan üreticilerin bu sektörde bilinçlendirilmesi ve bu faaliyetleri verimli bir șekilde sürdürmeleri adına önemli bazı avantajlar bulunmaktadır. Bunlar;

İlin geniş tarım ve mera arazileri sayesinde bol miktarda yem bitkileri üretiminin yapılması sonucu bitkisel üretim ve hayvancllık faaliyetleri için önemli bir potansiyelinin bulunması,
Gelișmekte olan önemli dıș pazarlara yakın ve genç işgücünün fazla ve ucuz olması,

$>\quad$ İlin geleneksel üretim çeşitliliğinin fazla olması,

> Tarımsal kirliliğin düșük olması nedeniyle organik tarım ve iyi tarıma elverişli olması,

Yaz dönemi sebze ve meyve üretiminde geç, dönem hasat bakımından öneme sahip olması,

İlde bitkisel ve hayvansal üretimin giderek artmasının, tarıma dayalı sanayinin gelişmesine katkı sağlama potansiyelinin bulunması,

bulunması.

Cok sayıda küçükbaş ve büyükbaş hayvanın

$\mathrm{Bu}$ çalışmada tespit edilen eksikliklerin ortadan kaldırılması ya da azaltılmasıyla, hedef kitlenin bitkisel ve hayvansal üretim potansiyellerinin arttırılması mümkündür. Tespit edilen bazı eksiklikler özetlendiğinde;

$>\quad$ Verimsiz tarım arazilerinin hububat ve yem bitkileri üretiminde kullanılması,

> Düşük verimli hayvanların bulunması ve kaliteli damızlıkların temin edilememesi,

$>\quad$ Çiftçilerin arazilerinin küçük olması ve arazi toplulaştırılmasına ihtiyaç duyulması,

$>\quad$ Bölgede tarımsal teknolojinin yeterli düzeyde kullanılamaması,

$>\quad$ Üreticilerin bitkisel ve hayvansal üretim konusunda yeterli bilgi düzeyine sahip olmaması,

$>\quad$ Bölgede silaj vb. kaliteli kaba yemlerin yetersizliği ve kalitesiz kaba/kesif yemlerin hayvan beslemede kullanılması,

$>\quad$ Meraların verimsiz olması, mera otlatma kurallarına uyulmaması ve meralarda içme suyu sorunlarının olması,

$>\quad$ Yem maliyetleri ile ürün fiyatları arasında uçurum olması,

> Hayvan hastalıkları ile mücadelenin yetersiz olması,

$>\quad$ Hayvan barınaklarının uygun olmaması ve modernizasyon desteklerinin yetersiz olması,

$>\quad$ Ürünlerin uygun fiyatlarla pazarlanamaması,

$>$ Tarımsal faaliyetlerde örgütlenmelerinin yeterince yaygin olmamasi,

$>\quad$ Bitkisel ve hayvansal üretim desteklerinden yeterince faydalanılamaması,

$>\quad$ Uygun hayvan besleme yöntemlerinin kullanılmaması,

Yasal ya da yasal olmayan şekilde yurtdışından getirilen ürünlerin yerli üretimi baskılaması gibi bahsi geçen eksiklikler, tarımsal faaliyetlerimizin geliştirilmesinin önünde engel olarak durmaktadır. Bu engellerin ortadan kaldırılmasında eğitimin büyük bir öneme sahip olduğu açıktır.

\section{TEŞEKKÜR}

Bu çalışmanın özeti 21-23 Haziran 2019 tarihinde Ankara'da düzenlenen Hasat Uluslararası Tarım ve Orman Kongresi'nde sözlü bildiri olarak sunulmuştur.

\section{KAYNAKLAR}

Anonim (2013). Van ili tarım ve hayvancllk raporu. http://www.vantso.org.tr/u/files/ tarim_son.pdf Erișim tarihi: 01.12.2018

Dedeoğlu M, Yıldırım İ (2006). Emek Tarımsal Kalkınma Kooperatifi'ne ortak işletmelerin ekonomik analizi. YYÜ Zir Fak, Tar Bil Derg, 16(1): 39-48

Demir PA, Işık SA, Aydın E, Yazıcı K, Ayvazoğlu C (2015). Socioeconomic importance of sheep breeding farms in Ardahan province. Van Vet J, 26 (3) 141-146 
Gençdal F, Terin M, Yıldırım İ (2016). Tarımsal Kalkınma Kooperatif ortağı olan ve olmayan süt sığırcllı̆̆ ișletmelerinin belirli kriterler açısından karşılaş̧tırılması: Van ili Gevaş ilçesi örneği. GOPÜ Zir Fak Derg 33 (1), 1-8 doi:10.13002/jafag905

Güzel M ve Aybek A (2017). Kahramanmaraş ili süt sığırcılı̆̆ işletmelerinin mekanizasyon yapısı. KSÜ Doğa Bil. Derg., 20(2), 148159, DOI : $10.18016 /$ ksujns.88470

Hozman SB ve Akçay H (2016). Sivas ili Damızlık Sı̆̆ır Yetiștiricileri Birliği'ne üye süt sığırcılığı işletmelerinin bazı teknik ve ekonomik özellikleri. Tar Eko Derg 22-1

Karakaya E ve Kızıloğlu S (2014). Küçükbaș hayvancllık işletmelerinin örgütlenme yapısı Bingöl ili örneği. Türk Tarım ve Doğa Bilimleri Dergisi 1(4): 552-560

Karakuş F, Akkol S (2013). Van ili küçükbaş hayvancılık işletmelerinin mevcut durumu ve verimliliği etkileyen sorunların tespiti üzerine bir araştırma. YYÜ Fen Bilimleri Enstitüsü Dergisi, 18 (1-2):09-16

Karaturhan B, Sevik T, Yıldız Ö (2014). Yetiștirici birliklerinin tarımsal kalkınmaya etkileri üzerine bir araştırma: Edirne Damızlık Sığır Yetiştiricileri Birliği örnek olayı. Ege Üniv. Ziraat Fak. Derg. 51 (2) 175 184

Şahin K ve Keskin B (2010). Van ili Gevaş ilçesinde yem bitkileri üreten işletmelerin mevcut durumu ve sorunları. Alınteri, 19 (B), 7-13 ISSN:1307-3311

Şahin K ve Yılmaz İH (2008). Van ilinde yem bitkileri tarımı, mera kullanımı ve sosyo ekonomik yapı üzerine bir araștırma. Ankara Üniversitesi Ziraat Fakültesi, Tarım Bilimleri Dergisi, 14 (4) 414-419
SAS (2014). SAS/STAT. Statistical analysis system for Windows. Released version 9.4. SAS Institute Incorporation, Carry, NC, USA

TÜíK (2017a). Ortalama hane halkı büyüklüğü. http://www.tuik.gov.tr/ PreHaber Bultenleri. do?id=27597 Erişim tarihi: 01.12.2018

Tüí (2017b). Gelir ve yaşam koşulları araştırması, 2016. http://www.tuik.gov.tr/ PreHaber Bultenleri. do?id= 24579 Erişim tarihi: 01.12.2018

TüíK (2017c). Tarımsal ișletme işgücü ücret yapısı, 2016 http://www.tuik.gov.tr/ PreHaber Bultenleri. do?id= 24565 Erișim tarihi: 01.12.2018

TüíK (2018a). Van ili tarım sektörü yatırım kllavuzu. http://www.daka.org.tr/panel/files/yayinlar/Van\%20\%C4\%B0li\%20 Tar\%C4\%B1m\%20Sekt\%C3\%B6r\%C3\%BC\%20Yat\%C4\%B1r\%C4\%B 1m\%20K\%C4\%B1lavuzu.pdf Erişim tarihi: 01.12.2018

TÜíK (2018b). İstatistik göstergeleri. http://www.tuik.gov.tr/ UstMenu. do?metod= istgosterge Erişim tarihi: 01.12.2018

Yavuz F, Terin M, Güler İo, Akay B, Denizli G (2014). Tarımsal üretimde kadının rolünün belirlenmesi üzerine bir çalışma: Bayburt ili örneği. XI. Ulusal Tarım Ekonomisi Kongresi 3-5 Eylül 2014, Samsun

Yıldız S, Akkol S, Deniz S (2019). Van Yüzüncü Yıl Üniversitesi DAP Çiftçi Eğitim Merkezi'nde Eğitim Alan Kursiyerlerin Tarımsal Okuryazarlık Kapasitelerinin Değerlendirilmesi. YYÜ Fen Bilimleri Enstitüsü Dergisi, Cilt 24, Sayı 2, 133-141 